Article

www.mdpi.com/journal/remotesensing

\title{
Identifying Spatial Units of Human Occupation in the Brazilian Amazon Using Landsat and CBERS Multi-Resolution Imagery
}

\author{
Ana Paula Dal'Asta *, Newton Brigatti, Silvana Amaral, Maria Isabel Sobral Escada and \\ Antonio Miguel Vieira Monteiro
}

Divisão de Processamento de Imagens (DPI), National Institute for Space Research (INPE), Av. dos Astronautas, 1758, São José dos Campos, CEP: 12227-010 SP, Brazil;

E-Mails: brigatti_n@yahoo.com.br (N.B.); silvana@dpi.inpe.br (S.A.); isabel@dpi.inpe.br (M.I.S.E.); miguel@dpi.inpe.br (A.M.V.M.)

* Author to whom correspondence should be addressed; E-Mail: anapdalasta@dpi.inpe.br; Tel.: +55-12-3208-6474; Fax: +55-12-3208-6468.

Received: 1 October 2011; in revised form: 21 December 2011 / Accepted: 21 December 2011 / Published: 4 January 2012

\begin{abstract}
Every spatial unit of human occupation is part of a network structuring an extensive process of urbanization in the Amazon territory. Multi-resolution remote sensing data were used to identify and map human presence and activities in the Sustainable Forest District of Cuiabá-Santarém highway (BR-163), west of Pará, Brazil. The limits of spatial units of human occupation were mapped based on digital classification of Landsat-TM5 (Thematic Mapper 5) image (30m spatial resolution). High-spatial-resolution CBERS-HRC (China-Brazil Earth Resources Satellite-High-Resolution Camera) images (5 m) merged with CBERS-CCD (Charge Coupled Device) images $(20 \mathrm{~m})$ were used to map spatial arrangements inside each populated unit, describing intra-urban characteristics. Fieldwork data validated and refined the classification maps that supported the categorization of the units. A total of 133 spatial units were individualized, comprising population centers as municipal seats, villages and communities, and units of human activities, such as sawmills, farmhouses, landing strips, etc. From the high-resolution analysis, 32 population centers were grouped in four categories, described according to their level of urbanization and spatial organization as: structured, recent, established and dependent on connectivity. This multi-resolution approach provided spatial information about the urbanization process and organization of the territory. It may be extended into other areas or be further used to devise a monitoring system, contributing to the discussion of public policy priorities for sustainable development in the Amazon.
\end{abstract}


Keywords: extensive urbanization; human occupation; Brazilian Amazon; remote sensing; multi-resolution data; digital image processing

\section{Introduction}

The largest area of continuous and preserved tropical forest in the world is in the Brazilian Amazon, covering 3,250,511 $\mathrm{km}^{2}$ [1]. However, during the past three decades, this region has experienced high rates of population increase and urban growth. From 2000 to 2010, while the population growth rate in Brazil was equal to $1.17 \%$, the Brazilian northern region growth rate was $2.09 \% ; 73.5 \%$ of this population is living in urban areas [2]. The urbanization rate of the Amazon increased from $42.6 \%$ in 1970 to $57.8 \%$ in 1991. This increase led Becker [3] to propose the term "urban forest" to describe the region; thus, she brought the issue of the urban space as an important part of this changing environment to the attention of the scientific community.

To comprehend the extent and meaning of urbanization in Amazonia, it is necessary to analyze more than the population growth in cities and towns in Amazonia. It is also necessary to look for transformation in the values of Amazon society [4]. Padoch et al. [5] argued that family networks related to the circulation of goods, access to employment, education, and health services spanning rural and urban areas make urban areas an integral part of the expansion of rural areas, and vice versa. They found evidence for new forms of household arrangements that connect urban and rural areas; these arrangements respond to opportunities and constraints created by limited service infrastructure, employment, and global commodities markets for regional products. They also observed that households from the Amazon "urban forest" continue to move to cities and redefine what it is to be urban, as well as what it means to be rural; these households are transforming the forests and cities in the Amazon territory. As stated by WinklerPrins and Souza [6], the 'rural' and 'urban' cannot be conveniently partitioned because they are highly interrelated; similarly, people cannot be easily categorized as "rural" or "urban". Browder [7] emphasizes the strong relationship between the urban and the rural in the Amazon by proposing a model of Urban-Rural Interface (URI) to understand decision making for the conversion of land use. According to Browder, this interface does not correspond simply to a geographic area or space between the urban built environment and rural landscape but to an array of networks connecting urban and rural agents.

Although new Amazonian cities play an important role in the territory, they have deficiencies in their basic infrastructure mainly because the historical focus of governmental occupation projects was to increase agro-pastoral production and assure territorial occupation instead of prioritizing urban public politics to organize the structure of cities [8]. In the nineties, Godfrey [9] analyzed towns in southeastern Pará and identified boom towns of the Amazon. He discussed settlement patterns based on the exploitation of natural resources that were encouraged by government intervention. One example of a boom town, also identified by Roberts [10], is Parauapebas; in Parauapebas rapid, intense population growth associated with mining in Carajás was not accompanied by the implementation of adequate infrastructure and state intervention. As result, the city, overloaded with demands, no longer had the capacity to house its population and perform its urban specific roles. 
To explain the structure of the Amazonian urban network, different authors have sought to understand how these population centers are articulated at different levels. Garcia et al. [11] postulated that the establishment of a territorial hierarchy, representing nested spatial levels of socioeconomic and demographic organization, provides a basis for the design of sustainable development policies based on each region's specific needs and that this spatial organization can be represented in terms of the urban network and the space under its influence. They proposed a model of territorial organization for the Brazilian Amazon based on the characteristics of its municipalities and consisting of the following two components: a hierarchy of cities as a function of urban specialized services, identifying poles of influence, and a measure of interaction among poles and municipalities, based on a socioeconomic index, distances and migratory flow. The model they presented added a new dimension to the large-scale regional divisions of the Brazilian Amazon, as first defined by Becker [12] and later developed by Amaral et al. [13] and Becker [14], and had the potential to predict environmental changes due to anthropic pressure, taking into account that the socioeconomic space network plays a decisive role in governing human settlement patterns.

Studying the hierarchy of urban areas, Guedes et al. [15] emphasized the increasing role of regional and sub-regional urban networks in shaping the future expansion of land use and population distribution in the Amazon, as proposed in the "disarticulated urbanization" model from Browder and Godfrey [16]. Using three general levels, the regional, sub-regional and local, they stressed the emergence of sub-regional urban networks characterized by economic and political interdependency, population movement, and the provision of services. They also observed that these sub-regional networks link rural areas, small towns, medium cities and large cities, and that medium-size cities are important nodes at the subregional level.

The data received from orbital remote sensing have been widely used as tools for identifying areas of human occupation, both in identifying intra-urban characteristics [17-20] and in delimiting urban sprawl and assessing the expansion of the human occupation [21-24]. These data offer fast, efficient and consistent sources of information on the evolution of urban land cover from global to intra-urban scales [25]. Spatial data from different scales is required to fully understand the complexity of urban structures given by the intricacies of urban spatial arrangements [20].

Cities are considered the key elements in the development and planning of the Amazon because they are the nodes of the regional relations network and because the population is concentrated in cities [4]. Currently, urban areas in the Amazon are not restricted to cities and villages; instead, these areas are characterized by a mosaic of entities, including municipalities, villages, settlement projects, riverine communities, indigenous areas and conservation units. Based on their own histories of use and occupation, these entities have distinct processes of evolution and consolidation [8].

Thus, this work contributes to the understanding of urban areas in the Amazon using the concept proposed by Monte-Mór [26] that the urban process is spread out within the territory and that every spatial unit of human occupation is part of this urbanized network structuring an extensive urbanization process [26]. Instead of working with the official urban network (IBGE-Brazilian Institute of Geography and Statistics and/or REGIC - Influence Regions of the Cities [27]), which only considers cities, we propose to analyze smaller territorial units that are defined by human presence and/or provide goods and services for local inhabitants, hereafter called spatial units of human occupation. These units include urbanized areas of municipality centers, smaller villages and 
communities, and even areas of human activities, such as sawmills, land stripping, that constitute the smallest contiguous units that can be detectable by remote sensing with medium spatial resolution. Once the spatial units were mapped, features observed by high-resolution remote sensing (such as bare soil, road patterns, different ceiling types, buildings, houses, sheds, and construction density) enable the description of internal spatial patterns and the classification of spatial units according to their internal arrangement.

This study assumes that urban areas in the Amazon are composed of non-continuous space that articulates different spatial typologies [8]. This work had the following two objectives: (1) to explore the potential of medium- and high-resolution satellite imagery to identify these spatial units of human occupation in the Amazon region, and (2) to present a categorization of the units with their resident populations based on the detected intra-urban spatial arrangements. The Sustainable Forest District (SFD) of the BR-163 road (SFD-BR163), linking the Brazilian cities of Cuiabá and Santarém, in the state of Pará, was chosen as study site.

\section{Methodology}

\subsection{Study Site}

The first SFD in Brazil was created in February 2006 in the southwest area of Pará state, which comprises the area of influence of the BR-163 highway (SFD-BR163). The Brazilian government created this administrative unit with the objective of promoting integrated local development activities based on forest exploitation [28]. Previous governmental research initiatives, such as the PIME project (Integrated Project Ministry of Science and Technology and Embrapa [29]), motivated the study of SFD-BR163 to evaluate the effectiveness of this unit as a compromise between local economic development based on forest resources and the improvement of quality of life combined with environmental conservation. To enable the continuity of previous research and fieldwork activities, the SFD-BR163 was defined as the study site, comprising $190,000 \mathrm{~km}^{2}$ in the municipalities of Altamira, Santarém, Placas, Rurópolis, Belterra, Itaituba, Novo Progresso, Trairão and Jacareacanga (Figure 1).

Previous studies have emphasized that the SFD-BR163 cannot be considered a uniform geopolitical unit, but rather that it is a mosaic of occupational dynamics that are derived from economic, demographic, and land use factors, as well as interactions between sites that have a human presence [30-32]. Generally, the following six distinct areas, which are characterized by different urbanized site arrangements and land use patterns, are defined in the region: (1) the great Santarém, (2) Itaituba, within the influence of the Tapajós River, (3) terrestrial Itaituba, (4) the area of influence of the Trans-Amazonian Highway, (5) the area of influence of the Transgarimpeira road (mining) and (6) Novo Progresso [32]. 
Figure 1. Study site: (A) Pará state in Brazil; (B) the Sustainable Forest District of the BR-163 highway (SFD-BR163); (C) political limits of the municipalities and the spatial units location in the SFD-BR163, with Landsat TM images references.

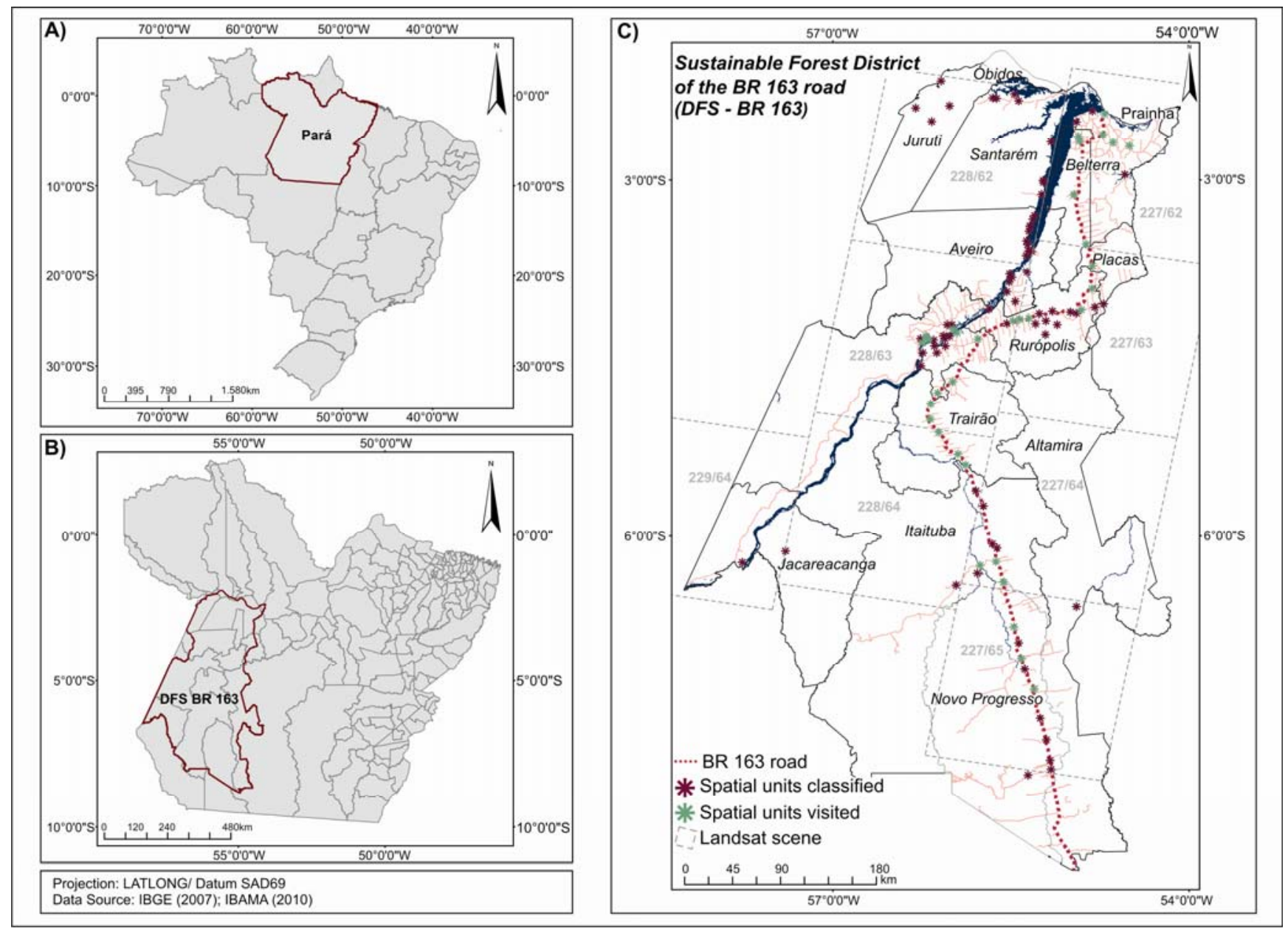

\subsection{Methodological Procedures}

According to Cardoso and Lima [8], there are different occupation typologies in the Amazon territory within municipal boundaries; these include cities, villages, riverine housing, rural villages, settlement projects, indigenous territories, small service centers and farmhouses. In each spatial typology, the inhabitants report to and require assistance from the municipal government or may even promote changes in the territory themselves. We expanded this spatial typology concept to include other land-cover features that indicate human presence in the territory and that constitute the smallest contiguous units detectable by remote sensing of medium spatial-resolution, such as sawmills, industrial plants, landing strips and community centers; these are referred to here as spatial units of human occupation. Following the IBGE criteria for defining population settlements [33], we use the term "urban" to refer to areas containing permanent and adjacent buildings that create a contiguous area along an arrangement of streets or a communication path. A methodological approach is proposed to assess the use of remote-sensing images to identify and map human presence and activities in the SFD-BR163. Medium-resolution images were first used to delineate the geographic limits of human presence and thus to identify the spatial units of human occupation. Land-cover features related to 
human settlements and activities, mostly related to built-up areas and bare soils, were the general references for image classification. Subsequently, the previously mapped regions were detailed and qualified as different types of spatial units of human occupation using high-resolution images. This qualification, described below, was based on classifications of the spatial patterns within each unit, which are analogous to intra-urban features.

Finally, ground truth information was used to validate the remote-sensing classification, and this enabled us to propose a categorization of the spatial units of human occupation for the study region as described below.

Considering that this study could form the basis of a monitoring system, we wanted to control the total cost to keep the option of applying this methodology to other, potentially much larger, regions open. Thus, we chose to base it upon freely available remote-sensing data, such as images from CBERS and Landsat sensors, and free/opensource Geographical Information System, and image-processing software. SPRING v5.1.6-Georeferenced Information Processing System [34] was used for the digital image processing, and TerraView v3.3.1 [26] was used as the GIS software; both were installed on a PC platform: $2.27 \mathrm{GHz}, 3 \mathrm{~GB}$ of RAM, $250 \mathrm{~GB}$.

\subsubsection{Identifying the Spatial Units of Human Occupation}

Initially, a geographical database was created to identify the spatial units of human occupation in the SFD-BR163. A total of eight Landsat TM5 images (using spectral bands TM3, TM4 and TM5) of the SFD-BR163 region that were acquired during 2008 and 2009 were selected from the image dataset available at Brazilian Amazon Forest Monitoring by Satellite Project (PRODES Project, http://www.obt.inpe.br/prodes/) of the Brazilian National Institute for Space Research (INPE) [1]. Images with high cloud cover in the PRODES Project database were replaced by images selected and acquired from INPE's online CBERS/Landsat images catalogue (http://www.dgi.inpe.br/CDSR/), and geo-referenced using past PRODES project images (Table 1).

Table 1. Landsat TM5 scenes selected for SFD-BR163.

\begin{tabular}{cccc}
\hline WRS & Data & WRS & Data \\
\hline $227 / 62^{* *}$ & $12 / 07 / 2009$ & $228 / 62^{* *}$ & $16 / 07 / 2008$ \\
$227 / 63^{*}$ & $12 / 07 / 2009$ & $228 / 63^{*}$ & $16 / 07 / 2008$ \\
$227 / 64^{*}$ & $12 / 07 / 2009$ & $228 / 64^{*}$ & $16 / 07 / 2008$ \\
$227 / 65^{* *}$ & $12 / 07 / 2009$ & $229 / 64^{*}$ & $11 / 08 / 2009$ \\
\hline
\end{tabular}

Visible and infrared spectral bands from the Landsat TM sensor have been widely used for land-use and urban studies in Brazil [22,35-37]. Landsat TM classification attempted to identify urban land use as built-up areas in municipality centers but also to identify other types of land use related to human presence. In the Amazon region, human occupation usually generates areas of bare soil that sharply contrast with the background forest cover. This is especially true of images from the infrared spectral bands. The size, density, and pattern of bare soil areas, created by the removal of the original forest cover, can indicate street layouts, vacant lots, lumber yards, and other land cover related to human presence. In empirical tests, the TM5-TM4 band difference was shown to improve the contrast between bare soil or built-up areas in the study site and the forest background (Figure 2(A)). Then a 
$3 \times 3$ average filter was applied over the band subtraction to smooth it and to prevent single-pixel detection during segmentation and classification procedures (Figure 2(B)).

To generate segmented images, an image-segmentation procedure based on a region-growing algorithm [38] implemented in SPRING was applied using a similarity threshold of 80 and an area threshold of 800 (Figure 2(C)). The similarity threshold define the minimum value at which two regions are considered spectrally similar based on statistical tests for mean digital values, and the area threshold is the minimum area, in pixels, requested to individualize a region [38]. A supervised classification based on the Bhattacharyya distance [39] was applied to the segmented image to identified single units of human occupation (Figure 2(D)). The classification scheme was designed to identify only one class, corresponding to the land cover types associated with human presence. Finally, the results of the automatic classification were scrutinized, and whenever necessary, visual interpretation and editing were performed to eliminate misclassifications; for example, bare soil areas related to erosion or soil management for agriculture were excluded from classification. In this final editing process, ancillary data available from previous official censuses and mapping activities [40,41] were also used to identify human activity.

Figure 2. Digital image processing steps used to identify spatial units of human occupation in the west Santarém region in the example below: (A) the TM5-TM4 subtraction image, (B) the image after $3 \times 3$ average filtering, (C) limits from the segmented image and (D) image classification.

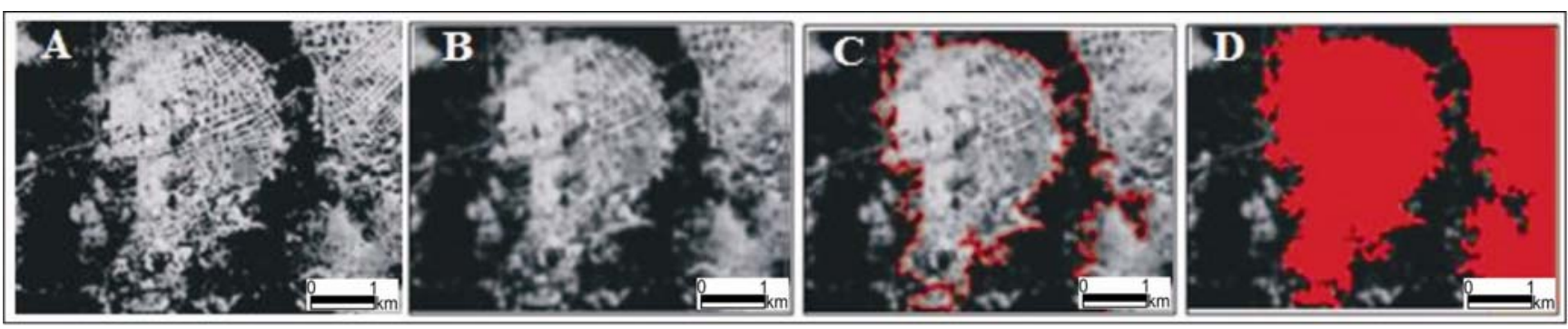

The final classification was verified with fieldwork performed in September 2010. The limits of the spatial units were recorded using GPS and the spatial units were coded by type as cities, districts, villages, communities, mining operations, sawmills and other. Cities and districts are defined by municipal and state legal boundaries and are identified as urban census tracts by IBGE; communities are small villages located in rural areas.

\subsubsection{Characterizing the Spatial Units of Human Occupation}

Characterization of the spatial units of human occupation was performed for those areas where the Landsat TM image classification identified units with resident populations, such as in cities, villages and communities. The objective was to perform a categorization of the spatial arrangements of these units supported by high-resolution remote sensing images based on the method that Cardoso and Lima [8] proposed for the cities in the lower Tocantins river basin and along the Transamazon Highway. These authors evaluated the characteristics of spatial arrangements such as spatial structure and access, and they identified factors consistent with consolidation, including connection, urban 
expansion and infrastructure, to characterize the typologies of the cities that had been identified using field observations and data from secondary sources.

CBERS-CCD and CBERS-HRC images from 2008 and 2009 with less than $10 \%$ of cloud cover over the area of interest were also selected from INPE's online dataset (Table 2). Landsat TM images (Table 1) were used as cartographical references for CBERS-CCD image registration and the georeferenced CBERS-CCD image was then used as a reference for the registration of the CBERS-HRC images. The spatial information from the geo-referenced CBERS-CCD images was improved by applying a restoration filter [42] that also resampled the image to a $10 \mathrm{~m}$ spatial resolution.

Table 2. CBERS-CCD and CBERS-HRC images of the study site.

\begin{tabular}{|c|c|c|}
\hline Year & CBERS-CCD & CBERS-HRC \\
\hline 2008 & $\begin{array}{l}167 / 104,167 / 105,167 / 108 \\
168 / 104,168 / 105,168 / 106 \\
168 / 107,169 / 104,169 / 105\end{array}$ & $\begin{array}{c}\text { 167-C-104-3, 167-C-104-4, } 167-\mathrm{C}-104-5,167-\mathrm{A}-107-3,167-\mathrm{A}-107-4 ; \\
167-\mathrm{C}-107-4,167-\mathrm{C}-107-5, \text { 167-D-108-4, 168-E-107-1, 168-E-107-2, } \\
\text { 168-E-107-3 }\end{array}$ \\
\hline 2009 & $167 / 107$ & $\begin{array}{c}\text { 168-D-104-2, 168-D-104-3, 168-D-104-4, 168-D-104-5, 168-D-105-1, } \\
\text { 168-D-105-2, 168-E-105-2, 169-E-105-3 }\end{array}$ \\
\hline $\begin{array}{l}2008 \\
\text { and } \\
2009\end{array}$ & & $\begin{array}{c}\text { 167-B-108-1, 167-B-168-2, 167-B-108-3, 167-B-108-4, 167-C-108-1, } \\
\text { 167-C-108-2, 167-C-108-3, 167-C-108-4, 167-C-105-1, 167-C-105-2, } \\
\text { 167-D-105-1, 167-D-105-2, 167-D-105-3, 167-D-105-4, 167-D-105-5; } \\
\text { 168-A-105-2, 168-A-105-3 }\end{array}$ \\
\hline
\end{tabular}

The CBERS-CCD and CBERS-HRC images were merged to obtain a remote sensing product that included spectral information (20 $\mathrm{m}$ for CCD) and better spatial resolution ( $2.7 \mathrm{~m}$ for HRC). This technique has been used in previous studies with satisfactory results and is very common in Brazil $[43,44]$. The method used was intensity-hue-saturation (IHS) as described by Pohl and Van Genderen [45]. The color compositions of the CBERS-CCD images (CCD5[R], CCD4 [G] and CCD3[B]) were transformed from the RGB color-attribute space to IHS [46]. Then the intensity band was replaced with the CBERS-HRC (panchromatic) to transform the images back from IHS to the RBG color-space domain [47].

Spatial patterns within the units of human occupation were visually interpreted from the fused CBERS-CCD/HRC color composite. Ancillary data, such as municipal master plans (when available), census tract boundaries from IBGE (2000) and fieldwork data, were used to identify general features. The variables collected during fieldwork: building pattern, urban services and facilities, accessibility, built up area, land use, industries and commercial establishments, were used to characterize and to establish a classification key for the spatial patterns (Table 3). Based on the color, shape, texture, organization and functionality within the spatial units of human occupation, we generated a synthetic map that contained the following classes: dense occupation; sparse occupation; expansion area; large, non-residential construction; and main access roads. The definitions of the concepts of "dense" and "sparse" used for class identification were adapted to the conditions of the Amazon region. Table 3 presents a description of each class with example images from remote-sensing imagery and photographs showing the general appearance on the ground. 
Table 3. Spatial patterns observed using CBERS-CCD/HRC fused images and fieldwork reference.

\begin{tabular}{|c|c|c|c|}
\hline $\begin{array}{l}\text { Spatial } \\
\text { Pattern }\end{array}$ & CBERS-CCD/HRC & Description & General appearance \\
\hline $\begin{array}{c}\text { Dense } \\
\text { Occupation }\end{array}$ & & $\begin{array}{l}\text { - Residential and commercial } \\
\text { buildings close to each } \\
\text { other } \\
\text { - Absence of non-built-up } \\
\text { urban areas } \\
\text { - Vegetation consisting of } \\
\text { trees and small cultivated } \\
\text { areas (kitchen } \\
\text { garden/manioc) }\end{array}$ & \\
\hline $\begin{array}{c}\text { Sparse } \\
\text { occupation }\end{array}$ & & $\begin{array}{l}\text { - Residential buildings that } \\
\text { are distant from each other } \\
\text { - Abundant non-built-up } \\
\text { urban areas with vegetation } \\
\text { - Vegetation consisting of } \\
\text { trees, grass and large } \\
\text { cultivated areas (manioc) }\end{array}$ & \\
\hline $\begin{array}{l}\text { Expansion } \\
\text { areas }\end{array}$ & & $\begin{array}{l}\text { - Sparse and new residential } \\
\text { buildings that are distant } \\
\text { from each other } \\
\text { - Abundant non-built-up } \\
\text { urban areas with bare soil }\end{array}$ & \\
\hline $\begin{array}{l}\text { Large non- } \\
\text { residential } \\
\text { constructions }\end{array}$ & & $\begin{array}{l}\text { - Non-residential areas } \\
\text { - Large constructions, such } \\
\text { as tool sheds, gymnasiums, } \\
\text { community centers, } \\
\text { sawmills and factories }\end{array}$ & \\
\hline $\begin{array}{l}\text { Main access } \\
\text { roads }\end{array}$ & & $\begin{array}{l}\text { - Non-built-up urban areas } \\
\text { surrounding highways or } \\
\text { rivers }\end{array}$ & \\
\hline
\end{tabular}

During the fieldwork, we travelled the main axes of spatial dispersion (usually performing two orthogonal routes) for each unit of human occupation mapped. Photographs were taken at the precise GPS locations, and general descriptions of the occupation patterns were recorded to describe the spatial variability along the routes. The photographs were geo-referenced and are available at INPE's fieldwork photograph database (2010-Cenarios/Santarém, [48]).

At this stage of our research, fieldwork data were used to interpret and validate the results from the multi-resolution approach. Assessments analyzing the accuracy of the automated system should be performed as we expand the mapping, and other, independent field data should be provided for statistical evaluation. 


\section{Results}

The minimum area mapped was $0.05 \mathrm{~km}^{2}$ at the classification of medium spatial-resolution images. We identified and delineated 133 spatial units of human occupation in SFD-BR163 that correspond to population centers and areas where infrastructure enables the development of human activities. From this total, 32 units represented population centers of different sizes. Approximately half of the classified units (46\%) were visited during the fieldwork (Figure 1).

Most individual spatial units of human occupation (95) were located in sectors identified as rural in the [41] census (Table 4); a priori these sectors are considered to be homogeneous areas and not human population aggregates. Such units are the smallest units of human occupation, generally called communities, and are not included in the IBGE criteria. The identification of these units is especially important for regional dynamics and relationships between the nodes of the urban network. Human settlements are the elementary structures used to understand the territorial organization.

Table 4. Spatial units of human occupation classified from remote sensing and verified during fieldwork.

\begin{tabular}{|c|c|c|c|c|c|c|c|}
\hline $\begin{array}{l}\text { Type of } \\
\text { Census } \\
\text { Tracts* }\end{array}$ & Classified & Verified & $\begin{array}{c}\text { Visited } \\
(\%)\end{array}$ & $\begin{array}{c}\text { Confirmed } \\
(\%)\end{array}$ & $\begin{array}{c}\text { Minimum area } \\
\text { classified } \\
\left(\mathbf{k m}^{2}\right) \\
\end{array}$ & $\begin{array}{c}\text { Maximum area } \\
\text { classified } \\
\left(\mathbf{k m}^{2}\right)\end{array}$ & $\begin{array}{c}\text { Total area } \\
\quad\left(\mathbf{k m}^{2}\right)\end{array}$ \\
\hline $\begin{array}{l}\text { Urbanized } \\
\text { area }\end{array}$ & 18 & 10 & 55.56 & 100 & 0.09 & 50.46 & 139.2 \\
\hline Rural village & 16 & 13 & 81.25 & 100 & 0.09 & 3.90 & 89.0 \\
\hline Rural zone & 95 & 38 & 40.00 & 97.36 & 0.05 & 2.37 & 89.5 \\
\hline $\begin{array}{l}\text { Special census } \\
\text { tracts** }\end{array}$ & 4 & 1 & 25.00 & 100 & 0.11 & 0.38 & 0.8 \\
\hline Total & 133 & 62 & 46.62 & 99.34 & - & - & 318.5 \\
\hline
\end{tabular}

* Census tracts defined by IBGE [41]: "Códigos de Situação e Tipo do Setor" from "Malha Municipal do Brasil";

** According to IBGE [49], special census tracts are: military areas, Indian reservations, penitentiaries, orphanages, convents, hospitals and others.

There was only one spatial unit of human occupation identified in the rural tracts of the IBGE census (Table 3) that, when checked in the field, was not directly associated with the presence of infrastructure for the development of human activities, and this unit was the result of soil erosion. The other units corresponded to population centers (23), sawmills (5), farmhouses (4), landing strips (2), a community center (1), a plant (1) and a cattle cold room (1). The special census tract [49] verified in the field was a military village in the municipality of Itaituba. Spatial units of human occupation in rural areas are important indicators of the development of economic activities, and they are related to new areas of urban expansion.

The digital automatic classification efficiently identified the boundaries of the spatial units of human occupation. This was true even in the case of tenuous boundaries where land coverage related to urbanized areas was mixed with agricultural activities. These mixed areas were characterized by a low density of buildings, empty lots, dense vegetation and frequent soil movement. In some cases, planned streets were already settled with recently built houses, indicating urban sprawl. 
Figure 3 presents some examples of spatial units of human occupation identified in the Landsat TM color composites. Large units (such as the city of Belterra; Figure 3(A)) or those that contain paved streets (such as Itacimpasa village; Figure 3(B)) are easily detected. Smaller units with unpaved streets can also be detected if they contain well-defined blocks such as those observed in the Mojuí dos Campos district (Figure 3(C)) and the community of São Jorge (Figure 3(D)). Areas of urban sprawl close to cities such as Santarém (Figure 3(E)) are detected, depending on their size, due to their contrast with the surrounding vegetation cover. Figure 3(F) illustrates the presence of industrial activity that is related to the exploitation of natural resources (e.g., sawmills), which is quite common in the region. Generally, the classification efficiently identified urban aggregates when they were situated next to roads. However, the classification failed to identify units adjacent to a river (riverine communities), such as the community of Curitimbó (Figure 3(G)). This was because the houses in such communities are usually sparse and surrounded by dense forest cover; this is the case even in larger areas, such as the district of Brasília Legal (Figure 3(H)).

Figure 3. Spatial units of human occupation identified using Landsat TM digital classification: (A) city of Belterra, (B) village of Itacimpasa, (C) district of Mojuí dos Campos, (D) São Jorge community, (E) Santarém urban sprawl area, (F) sawmill at Moraes de Almeida, (G) Curitimbó riverine community and (H) district of Brasília Legal.

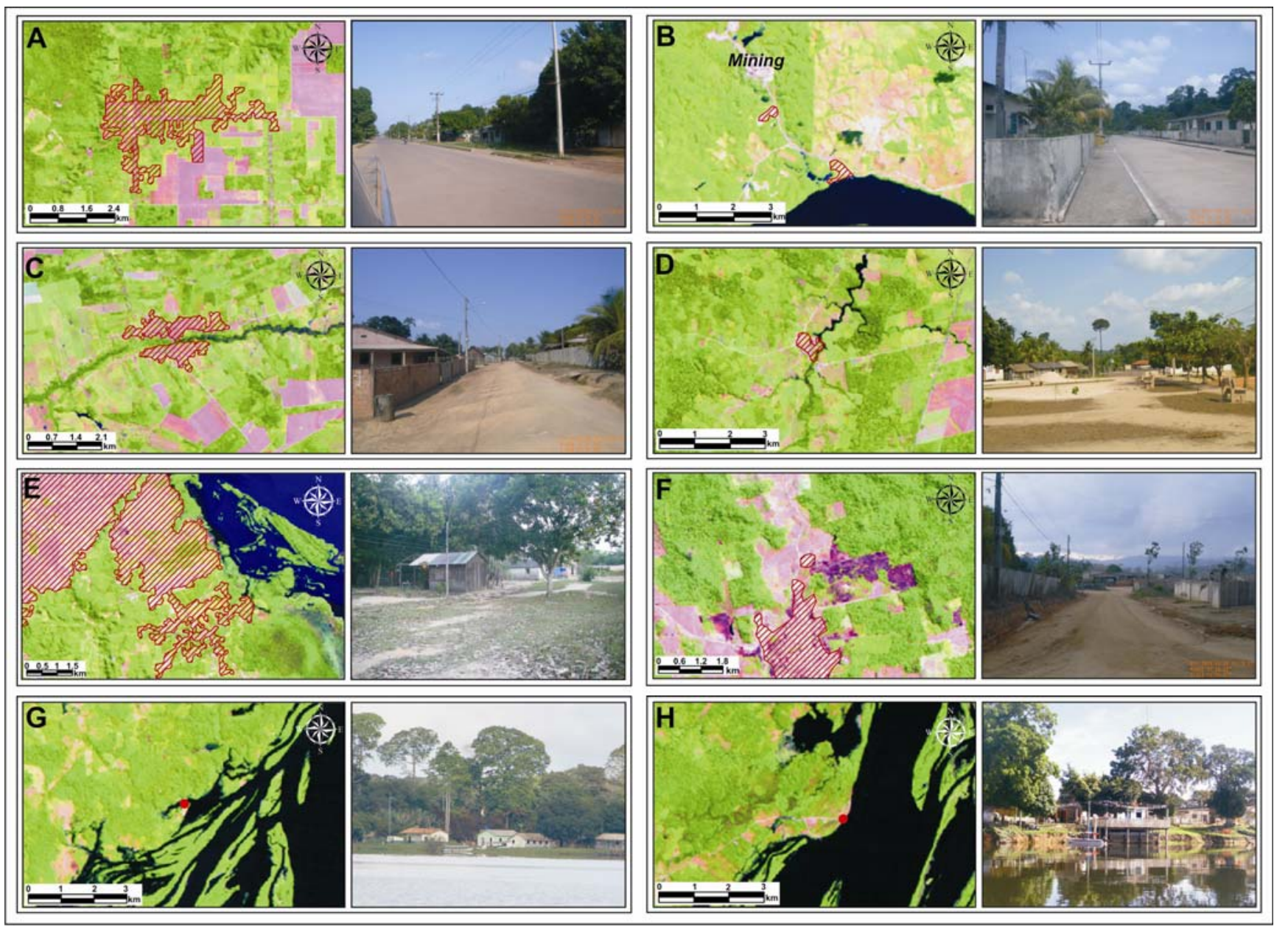


Spatial units of human occupation detected using the Landsat TM classification that were identified as municipal seats, districts and communities were interpreted with the fused CBERS-CCD/HRC image (Figure 4(A)). Spatial patterns observed from the high-resolution images were then mapped (Figure 4(B)) based on the characteristics of the density of occupation, as presented in Table 3.

Paired with the high-resolution approach, the fieldwork elucidated different patterns of human occupation and provided information about the functional characteristics found within each spatial unit. A total of 32 spatial units were evaluated, including six municipal centers, three district villages and 23 communities (Table 5). Based on the degree of urbanization and the spatial arrangements observed within these units, it was possible to aggregate them into four general categories: Structured, Established, Recent, and Dependent on Connectivity.

Figure 4. Boundaries of the spatial unit of human occupation obtained from Landsat TM for Novo Progresso over CBERS-CCD/HRC fused image (A) and spatial patterns mapping (B).

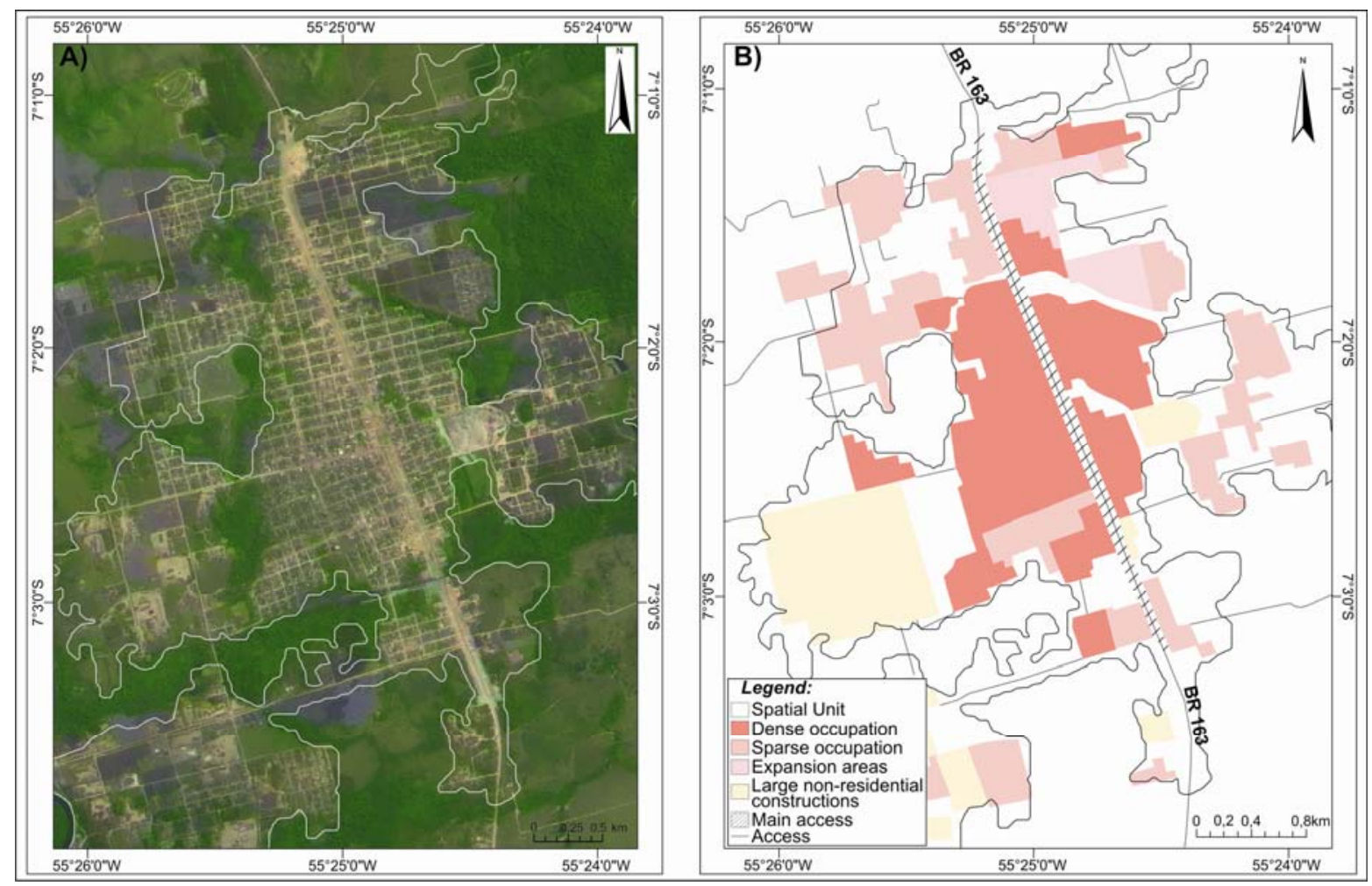

Table 5. Categories of spatial units of human occupation mapped and evaluated during fieldwork.

\begin{tabular}{ccccccc}
\hline Spatial Unit & Typology & Municipality & $\begin{array}{c}\text { Foundation } \\
\text { Date }\end{array}$ & Connectivity & Population & Category \\
\hline Itaituba & City & Itaituba & 1856 & $\begin{array}{c}\text { Tapajós River/BR230 } \\
\text { road }\end{array}$ & Tapajós, Amazonas & Structured \\
Santarém & City & Santarém & 1848 & River/BR163 road & $215,790 *$ & Structured \\
Vila Bode & Community & Belterra & $1930-35$ & side road & 413 & Established \\
Belterra & City & Belterra & 1947 & side road & $6,852 *$ & Established \\
Betânia & Community & Belterra & 1975 & BR163 road & 200 & Recent \\
São Jorge & Community & Belterra & 1972 & side road & 3,000 & Recent \\
\hline
\end{tabular}


Table 5. Cont.

\begin{tabular}{|c|c|c|c|c|c|c|}
\hline Itacimpasa & Community & Itaituba & & side road & 600 & Recent \\
\hline $\begin{array}{c}\text { Nova } \\
\text { Esperança }\end{array}$ & Community & Itaituba & 1980 & BR163 road & 720 & Recent \\
\hline Km 30 & Community & Itaituba & & BR230 road & $1,666^{@}$ & Recent \\
\hline $\begin{array}{l}\text { Jardim do } \\
\text { Ouro }\end{array}$ & Community & Itaituba & 1984 & Transgarimpeira road & 500 to 600 & Recent \\
\hline $\begin{array}{c}\text { Riozinho das } \\
\text { Arraias }\end{array}$ & Community & $\begin{array}{c}\text { Novo } \\
\text { Progresso }\end{array}$ & 1985 & BR163 road & 550 & Recent \\
\hline $\begin{array}{l}\text { Alvorada da } \\
\text { Amazônia }\end{array}$ & Community & $\begin{array}{c}\text { Novo } \\
\text { Progresso }\end{array}$ & 1980 & BR163 road & 5,000 & Recent \\
\hline Santa Júlia & Community & $\begin{array}{c}\text { Novo } \\
\text { Progresso }\end{array}$ & & BR163 road & $33 * *$ & Recent \\
\hline Novo Paraíso & Community & Placas & & BR163 road & $58 * *$ & Recent \\
\hline $\begin{array}{l}\text { Estrela do } \\
\text { Norte }\end{array}$ & Community & Rurópolis & 1981 & BR163 road & 240 & Recent \\
\hline Água Azul & Community & Rurópolis & 1985 & BR163 road & 700 & Recent \\
\hline Divinópolis & Community & Rurópolis & & BR163 road & $2,464^{@}$ & Recent \\
\hline São José & Community & Rurópolis & & BR163 road & $115^{* *}$ & Recent \\
\hline $\begin{array}{c}\text { Boa } \\
\text { Esperança }\end{array}$ & Community & Santarém & 1962 & side road & 3,500 & Recent \\
\hline Tucunaré & Community & Trairão & & BR163 road & 70 & Recent \\
\hline $\begin{array}{c}\text { Bela Vista do } \\
\text { Caracol }\end{array}$ & Community & Trairão & & BR163 road & 7,200 & Recent \\
\hline Jamanxim & Community & Trairão & & BR163 road & 1,200 & Recent \\
\hline TrêsBueiras & Community & Trairão & & BR163 road & $28^{* *}$ & Recent \\
\hline $\begin{array}{c}\text { Moraes } \\
\text { Almeida }\end{array}$ & District & Itaituba & 2002 & BR163 road & $3,504^{@}$ & Recent \\
\hline Miritituba & District & Itaituba & 1993 & $\begin{array}{c}\text { Tapajós River / } \\
\text { BR230 road }\end{array}$ & $4,500^{@}$ & Recent \\
\hline Trairão & City & Trairão & 1991 & BR163 road & $5,679^{*}$ & Recent \\
\hline $\begin{array}{c}\text { Novo } \\
\text { Progresso }\end{array}$ & City & $\begin{array}{c}\text { Novo } \\
\text { Progresso }\end{array}$ & 1991 & BR163 road & $17,717^{*}$ & Recent \\
\hline Rurópolis & City & Rurópolis & 1988 & $\begin{array}{c}\mathrm{BR} 163 \text { and } \mathrm{BR} 320 \\
\text { roads }\end{array}$ & $15,273^{*}$ & Recent \\
\hline Aruri & Community & Itaituba & 1930 & BR163 road & 160 & Dependent \\
\hline Nova Canaã & Community & Itaituba & 1930 & $\begin{array}{l}\text { Tapajós River / } \\
\text { BR230 road }\end{array}$ & 220 & Dependent \\
\hline Taboca & Community & Santarém & & side road & 15,455 & Dependent \\
\hline $\begin{array}{l}\text { Mojuí dos } \\
\text { Campos }\end{array}$ & District & Santarém & 1964 & side road & $5,940^{@}$ & Dependent \\
\hline
\end{tabular}

${ }^{1}$ The year that the municipality was decreed by law and the year that the community was raised to the category of district by municipal law; ${ }^{2}$ Since 1998, this neighborhood of Belterra has been known as Bairro Santa Luzia; * Urban Population, [2]; ${ }^{@}$ IBGE Census [2]; ** Population estimated from surfaces [50].

The cities of Santarém and Itaituba are the oldest spatial units in the study area and they correspond to the seats of municipalities with high degrees of urbanization; $73.25 \%$ of the population of Santarém 
and $72.49 \%$ of the population of Itaituba live in urban zones, whilst the state average is $68.5 \%$ of the population living in seats municipalities [2]. Both cities provide most of the required commercial services and health and education infrastructures for the area, and they are consequently central units that attract people from other population units. These cities were categorized as Structured. In terms of spatial patterns, they have a historical center with intense commercial activity (Figure 5(A)) and branch offices of several governmental institutions. Residential areas range from sparse to dense, with variable patterns of construction (Figure 5(B,C)). The concurrent access provided by the river and the road network has enabled the evolution of these urban centers and has strengthened their central status.

Figure 5. Spatial patterns verified within the units of human occupation that were categorized as Structured: (A) Itaituba-central commercial area; (B) Itaituba-sparse residential occupation and (C) Santarém-residential area with wealthy construction pattern.
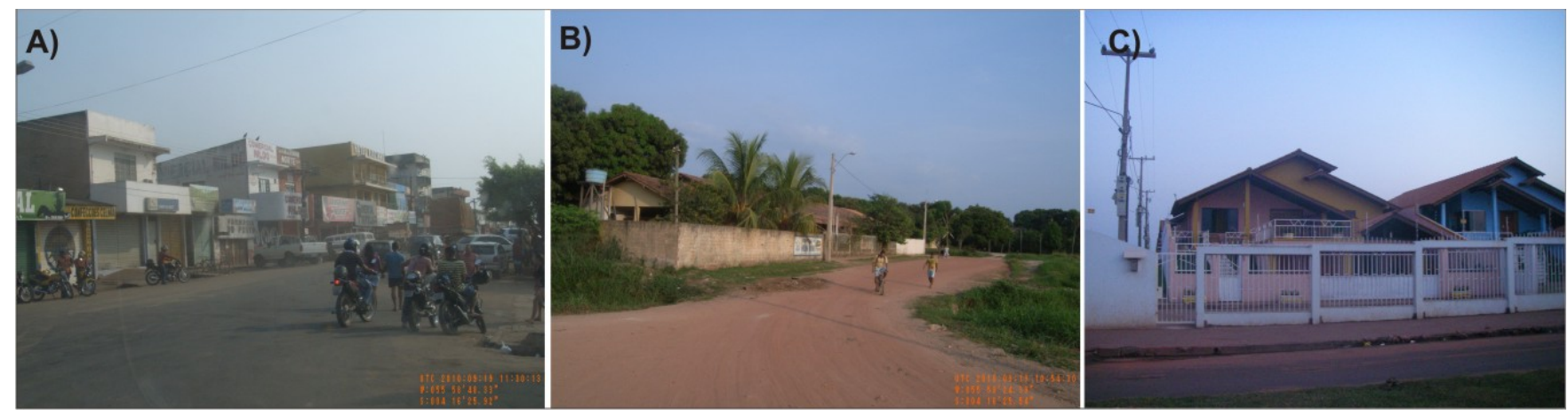

The Brazilian rubber boom was the origin of the old, traditional units of human occupation that are categorized here as Established. These units contain urban infrastructure, but they rely on larger centers for health, education and even commercial needs. The main activity in these units is related to municipal public services. Belterra and Vila Bode were planned units and contain basic infrastructure, but their populations depend on Santarém for health, education and commercial needs. There are large blocks with sparse occupation that contain traditional houses (Figure 6(A)) or preserved houses in the American style from the period when the Americans founded Fordlândia (approximately 1930; Figure 6(B)).

Figure 6. Spatial patterns verified within the units of human occupation that were categorized as Established: (A) occupation of Belterra; (B) American-style building-the school at Vila Bode.

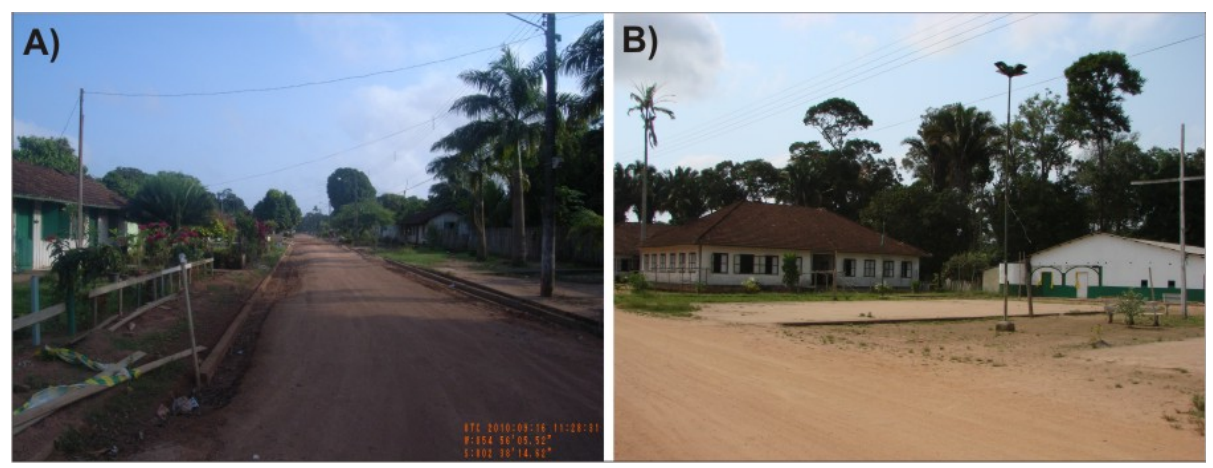


Modern units of human occupation are closely related to recent population dynamics that have arisen as a result of Brazilian governmental projects for Amazonian territorial occupation [51]. In the SFD-BR163, the units categorized as Recent are primarily near the main highways, namely the BR-163 and the Trans-Amazonian Highway (BR-230). They are secondarily related to other side roads, including the Transgarimpeira road, a Pará state highway. Oliveira [52] explained that urban centers based on the presence of roads constitute "very rapid transformations in which new life and spatial forms originate from nothing and flows of trade and business centers predominate (especially those related to mining, logging and, more recently, soybean production)". Recent units of human occupation provide basic urban services and limited commercial activity and their economy is based on the exploitation of natural resources. Instead of a traditional population, migrants from the south, northeast and center-west regions of Brazil predominate; this results in a cultural setting that is foreign to the Amazonian territory.

In contrast to the previous categories, the commercial center of these units is located in the vicinity of roads, restaurants, gas stations, drugstores, hotels and even clothing stores (Figure 7(A,B)). The concentration of activities spreads out from the roads toward the interior along perpendicular streets. In populated units where gold mining is the prevalent economic activity (such as in Jardim do Ouro on the Transgarimpeira road), there are also gold trade houses and a concentration of hostels along the road.

The units categorized as Recent are characterized by the following: spread-out occupation with wide lots; frequent, small agricultural cover; empty urban spaces; and wide, wooded streets. In peripheral areas, access to urban services and equipment is scarce, roads are poorly maintained and housing construction standards are low (Figure 7(C,D)). The physical environment imposes natural barriers that prevent occupation such as steep slopes and flooded areas. In riverine communities or areas next to rivers, houses built on stilts are common (this is a cultural practice; Figure 7(E)).

Figure 7. Spatial patterns verified within the units of human occupation categorized as Recent: (A) a road with a commercial center, (B) commercial establishments, (C) a peripheral street, (D) sparse housing occupation and (E) housing on stilts (palafitas).
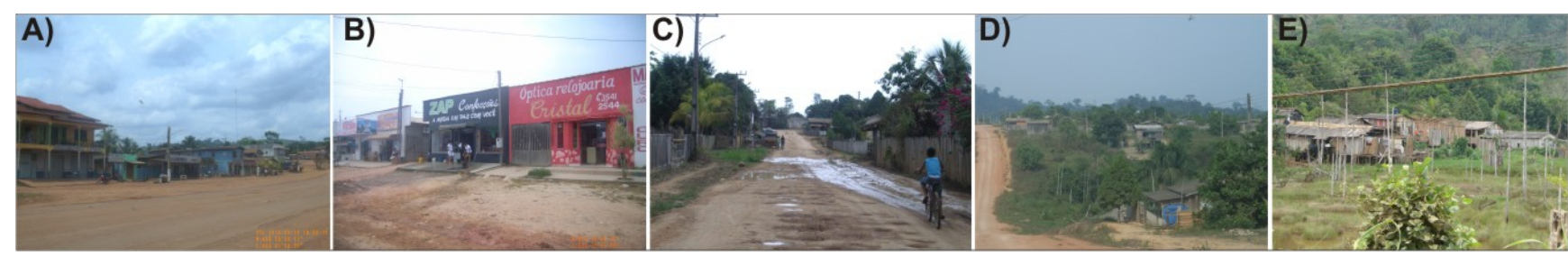

The presence of enterprises (such as sawmills and industrial plants) creates jobs and increases local incomes while at the same time modify the spatial patterns of occupation. Generally located within the urban boundaries or close to the urban occupation units, these enterprises attract laborers who prefer to live close to their places of work. This population settles nearby and their settlement results in residential areas of varying sizes. During the fieldwork, the most common enterprises observed were pottery in Santarém, sawmills along the Trans-Amazon and BR-163 highways (from Itaituba to Novo Progresso), charcoal production in Novo Progresso, and mining in Itaituba.

Each unit of human occupation is also shaped by areas of expansion and consolidation that are based on connections with other centers and the types of connections available (e.g., roads, rivers and 
communication networks). Units where access is mainly provided by roads are more closely tied to regional markets because they have better access to other cities. These units are more dynamic than the units that are only accessible by rivers. The current process of paving the BR-163 highway is bringing more investment and commercial initiatives, and it is improving the local economy; this improvement was evident in the urban development observed during fieldwork in the city of Novo Progresso.

Some units of human occupation are characterized by stagnant economies and are dependent on their connectivity with other urban centers for all basic urban services. They were categorized here as Dependent on connectivity, and the communities of Aruri and Nova Canaã are examples of these types of units. These are old population settlements with deficient infrastructure that are completely dependent on access to Itaituba by river or roads. They are composed of sparse housing areas on the road and/or beside the river, but they are disconnected from the regional dynamics of the road system (Figure 8).

Figure 8. Spatial patterns verified within the units of human occupation categorized as Dependent on connectivity: (A) Taboca; (B) Aruri; (C) Nova Canaã.
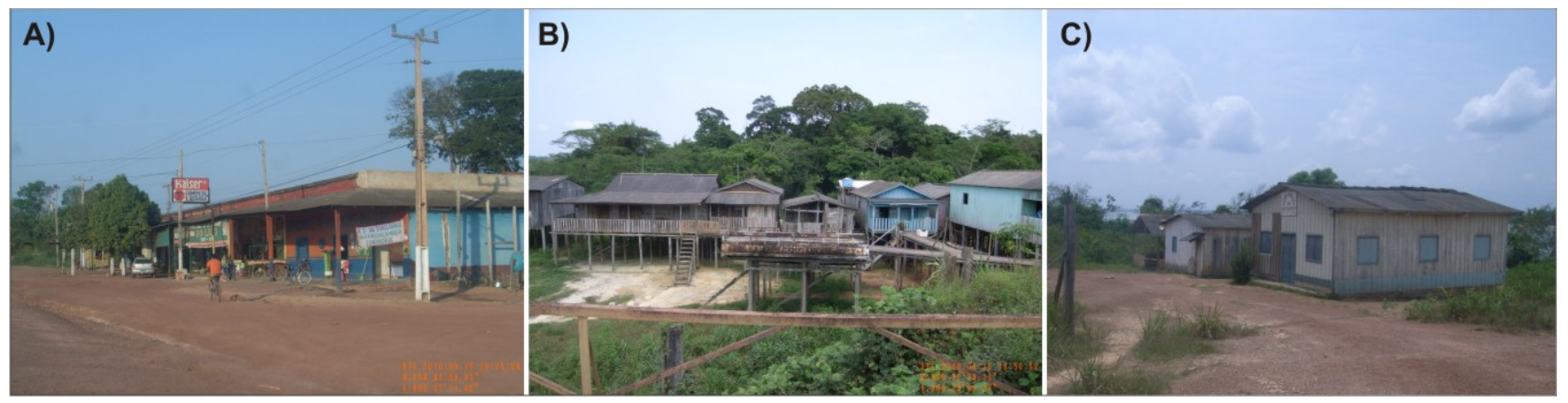

The digital image classification of spatial units of human occupation and the fusion of CBERS images procedures can be automated. However, human interpretation and field information related to land cover features was fundamental to obtaining the final results, especially given the heterogeneity of the occupation processes in the Amazon.

Using field information captured in the ground by photographs and descriptions, it was possible to create the interpretation key for physical features detected by high-resolution images within the spatial units and therefore classify the structure and function of these units. This basic knowledge enables the mapping of other areas in the Amazon. However, prior basic knowledge about the history and prevailing economic activities is fundamental to associate remote sensing patterns with specific functions in spatial units. For example, the structure of spatial units of human occupation located in regions where timber production is the main activity differs from regions of cattle-raising or regions where agriculture activities predominate and from spatial units located inside conservation areas.

This proposed methodology might be repeated for another time period to observe the persistence and/or evolution of these units and the emergence of other units; such analyses would enhance the monitoring of the urbanization process taking place over the region. 


\section{Conclusions}

Traditional remote-sensing methodology for urban detection was adapted here to identify spatial units of human occupation within the Amazon forest region. We assumed that the urban process is spread out within the territory and that every spatial unit of human occupation is part of the urbanized network that we want to describe.

Using Landsat TM image classification, we identified the spatial units of human occupation in the SFD-BR163 area. The classification identified not only spatial units with resident populations but also units with indications of human activities. Using the CBERS-CCD/HRC fused images, the spatial patterns within each populated unit were mapped, enabling a categorization of these units. This categorization is more than an example of high-resolution remote sensing application; in addition, it is a tool to understand the articulation of Amazon urban space and it could be useful for defining priorities for public policies that pursue sustainable development.

The multi-resolution approach and the categorization proposed in this work can be further improved using spatial metrics to describe the function of each unit based on the configuration of its spatial patterns. The next challenge is to develop a methodology to automatically extract the spatial patterns from high-resolution images based on the description criteria presented. This would facilitate future fieldwork by reducing the number of units to be sampled and it would enable replication of this approach for other areas in the Amazon region.

\section{Acknowledgments}

The authors thank the projects "Cenários para Amazônia" (MCT/FINEP/CNPq) and "LUA-Land Use Change in Amazonia: Institutional Analysis and Modeling at multiple temporal and spatial scales" (FAPESP) and the Division of Image Processing (DPI) of the National Institute for Space Research (INPE) for supporting the scholarship and the field. We also appreciate the work of all five reviewers who contributed for the improvement of this document.

\section{References}

1. INPE. PRODES: Programa de Monitoramento do Desmatamento da Amazônia por Satélite; 2010. Available online: http://www.obt.inpe.br/prodes/ (accessed on 15 April 2011).

2. IBGE. Censo Demográfico; 2010. Available online: http://www.ibge.gov.br/servidor arquivos_est/ (accessed on 20 October 2011).

3. Becker, B.K. Undoing myths: The Amazon-An urbanized forest. In Brazilian Perspectives on Sustainable Development of the Amazon Region; Man and Biosphere Series; Sachs, G.M.C.I., Ed.; UNESCO e Pathernon Publish Group Limited: Paris, France, 1995; pp. 53-89.

4. Becker, B.K. Geopolítica da Amazônia. Estudos Avançados 2005, 19, 71-86.

5. Padoch, C.; Brondizio, E.; Costa, S.; Pinedo-Vasquez, M.; Sears, R.R.; Siqueira, A. Urban forest and rural cities: Multi-sited households, consumption patterns, and forest resources in Amazonia. Ecol. Soc. 2008, 13, art. 2.

6. WinklerPrins, A.M.G.A.; de Souza, P.S. Surviving the city: Urban home gardens and the economy of affection in the Brazilian Amazon. J. Latin Amer. Geogr. 2005, 4, 107-126. 
7. Browder, J.O. The urban-rural interface: Urbanization and tropical forest cover change. Urban Ecossystems 2002, 6, 21-41.

8. Cardoso, A.C.D.; Lima, J.J.F. Tipologias e padrões de ocupacao urbana na Amazônia Oriental: Para que e para quem? In O Rural e o Urbano na Amazônia. Diferentes olhares e perspectivas; Cardoso, A.C.D., Ed.; EDUFPA: Belém, PA, Brazil, 2006; pp. 55-98.

9. Godfrey, B.J. Boom towns of the Amazon. Geogr. Rev. 1990, 80, 103-117.

10. Roberts, J.T. Squatters and urban growth in Amazonia. Geogr. Rev. 1992, 82, 441-457.

11. Garcia, R.A.; Soares-Filho, B.S.; Sawyer, D.O. Socioeconomic dimensions, migration, and deforestation: An integrated model of territorial organization for the Brazilian Amazon. Ecol. Indic. 2007, 7, 719-730.

12. Becker, B. Amazônia, 2nd ed.; Editora Ática: Rio de Janeiro, Brazil, 1990.

13. Amaral, S.; Camara, G.; Monteiro, A.M.V. Configurações Espaciais do Processo de Desflorestamento da Amazônia; INPE: São José dos Campos, Brazil, 2001.

14. Becker, B.K. Revisão das políticas de ocupação da Amazônia: é possível identificar modelos para projetar Cenários? Revista Parcerias Estratégicas 2001, 12, 135-159.

15. Guedes, G.; Costa, S.; Brondizio, E. Revisiting the hierarchy of urban areas in the Brazilian Amazon: a multilevel approach. Popul. Environ. 2009, 30, 159-192.

16. Browder, J.O.; Godfrey, B.J. Rainforest Cities: Urbanization, Development, and Globalization of the Brazilian Amazon; Columbia University Press: New York, NY, USA, 1997.

17. Herold, M.; Gardner, M.E.; Roberts, D.A. Spectral resolution requirements for mapping urban areas. IEEE Trans. Geosci. Remote Sens. 2003, 41, 1907-1919.

18. Greenhill, D.R.; Ripke, L.T.; Hitchman, A.P.; Jones, G.A.; Wilkinson, G.G. Characterization of suburban areas for land use planning using landscape ecological indicators derived from Ikonos-2 multispectral imagery. IEEE Trans. Geosci. Remote Sens. 2003, 41, 2015-2021.

19. Souza, I.M. Análise do espaço intra-urbano para estimativa populacional intercensitária utilizando dados orbitais de alta resolução espacial; Instituto de Pesquisa e Desenvolvimento da Universidade do Vale do Paraíba: São José dos Campos, SP, Brazil, 2004.

20. Amorin, L.; Barros Filho, M.N.; Cruz, D. Urban Texture and Space Configuration: Analysing Recife's Urban Fragments. In Proceedings of 7th International Space Syntax Symposium, Stockholm, Sweden, 6-8 June 2009.

21. Chen, S.; Zeng, S.; Xie, C. Remote sensing and GIS for urban growth analysis in China. Photogramm. Eng. Remote Sensing 2000, 66, 593-598.

22. Guindon, B.; Zhang, Y.; Dillabaugh, C. Landsat urban mapping based on a combined spectral-spatial methodology. Remote Sens. Environ. 2004, 92, 218-232.

23. Pereira, M.N.; Gonçalves, C.D.A.B.; Souza, I.M.; Garcia, S.; Portela, A.G.; Almeida, C.M.; Rosemback, R.; Florenzano, T.G. Uso de imagens de satélite como subsídio ao estudo do processo de urbanização; INPE: São José dos Campos, SP, Brazil, 2005; p. 39.

24. Karaburun, A.; Demirci, A.; Suen, I. Impacts of urban growth on forest cover in Istanbul (1987-2007). Environ. Monit. Assess. 2010, 166, 267-277.

25. Powell, R.L.; Roberts, D.A. Characterizing Variability of the urban physical environment for a suite of cities in Rondônia, Brazil. Earth Interact. 2008, 12, 1-32. 
26. Monte-Mór, R.L. Urbanização extensiva e novas lógicas de povoamento: um olhar ambiental. In Território: Globalização e Fragmentação; Santos, M.; Souza, M.A.; Silveira, M.L., Eds.; Hucitec/Anpur: São Paulo, Brazil, 1994; pp. 169-181.

27. IBGE. Região de Influência das Cidades-REGIC 2007; IBGE: Rio de Janeiro, Brazil, 2008.

28. MMA. Plano de Ação 2006-2007: Grupo de trabalho interinstitucional do Distrito Florestal da BR-163; MMA: Brazil, 2006; p. 27.

29. MCTI. Integração dos Programas do MCT e da Embrapa na Amazônia-PIME. Available online: http://www.mct.gov.br/index.php/content/view/43742.html (accessed on 22 October 2011).

30. Alves, P.A.; Amaral, S.; Escada, M.I.S.; Monteiro, A.M.V. Explorando as relações entre a dinâmica demográfica, estrutura econômica e mudanças no uso e cobertura da terra no sul do Pará: lições para o Distrito Florestal Sustentável da BR 163. Geografia (Rio Claro) 2010, 35, 165-182.

31. Amaral, S.; Andrade, P.R.; Escada, M.I.S.; Alves, P.A.; Pinheiro, T.F.; Pinho, C.M.D.; Medeiros, L.C.C.; Saito, É.A.; Rabelo, T.N. Da Canoa à rabeta: estrutura e conexão das comunidades ribeirinhas no Tapajós (PA). Pesquisa de Campo Jun/Jul de 2009; INPE: São José dos Campos, Brazil, 2009; p. 30.

32. Escada, M.I.S.; Amaral, S.; Rennó, C.D.; Pinheiro, T. Levantamento do Uso e Cobertura da Terra e da rede de infra-estrutura no Distrito Florestal da BR-163; INPE: São José dos Campos, Brazil, 2009; p. 52.

33. IBGE. Censo Demográfico 2000. Agregados por Setores Censitários dos Resultados do Universo; IBGE: Rio de Janeiro, Brazil, 2003.

34. Camara, G.; Souza, R.C.M.; Freitas, U.M.; Garrido, J. SPRING: Integrating remote sensingnad GIS by object-oriented data modelling. Comput. Graph. 1996, 20, 395-403.

35. Camara, G.; Valeriano, D.M.; Soares, J.V. Metodologia para o cálculo da taxa anual de desmatamento na Amazônia Legal; INPE: São José dos Campos, Brazil, 2006; p. 24.

36. Ferraz, S.F.B.; Vettorazzi, C.A.; Theobald, D.M.; Ballester, M.V.R. Landscape dynamics of Amazonia deforestation between 1984 and 2002 in central Rondônia, Brazil: Assessment and future scenarios. Forest Ecol. Manage. 2005, 204, 67-83.

37. Correia, V.R.M.; Monteiro, A.M.V.; Carvalho, M.S.; Werneck, G.L. Uma aplicação do sensoriamento remoto para a investigação de endemias urbanas. Cadernos de Saúde Pública 2007, 23, 1015-1028.

38. Bins, L.S.; Fonseca, L.M.G.; Erthal, G.J.; Mitsuo, F., II. Satellite imagery segmentation: A region growing approach. In Proceedings of VII Simpósio Brasileiro de Sensoriamento Remote (SBSR), Salvador, Brazil, 1996; pp. 677-680.

39. Kailath, T. The divergence and Battacharya distante measures in signal selection. IEEE Trans. Commun. Tech. 1967, 15, 52-60.

40. IBAMA. Dados Vetoriais. Available online: http://siscom.ibama.gov.br/shapes/ (accessed on 14 April 2010).

41. IBGE. Malha Municipal do Brasil. Available online: ftp://geoftp.ibge.gov.br/ (accessed on 23 March 2010).

42. Fonseca, L.M.G.; Prasad, G.S.S.D.; Mascarenhas, N.D.A. Combined interpolation-restoration of Landsat imagens through FIR filter design techniques. Int. J. Remote Sens. 1993, 14, 2547-2561. 
43. Abdon, M.M.; Oliveira, M.; Luciano, A.C.S.; Silva, J.S.V. Identificação e mapeamento de pastagens degradadas nos municípios de Corguinho e Rio Negro, MS, utilizando fusão de imagens CBERS-2B (CCD e HRC). In Proceedings of II Simpósio de Geotecnologias no Pantanal, Corumbá, Brazil, 7-11 November 2009; pp. 343-352.

44. Salgado, M.P.G.; Trabaquini, K.; Oliveira, P.V.C.; Pereira, F.R.S. Análise de paisagem auxiliar por fusão de imagens orbitais e modelo digital de elevação. In Proceedings of II Simpósio de Geotecnologias no Pantanal, Corumbá, Brazil, 7-11 November 2009; pp. 593-602.

45. Pohl, C.; Van Genderen, J.L. Review article Multisensor image fusion in remote sensing: Concepts, methods and applications. Int. J. Remote Sens. 1998, 19, 823-854.

46. Foley, J.D.; Van Dam, A.; Feiner, S.K.; Hughus, J.F. Computer Graphics: Principles and Practice, 2nd ed.; Addison Wesley: Boston, MA, USA, 2000.

47. Namikawa, L.M. Fusão de Imagens de Satélite CBERS-2B no Spring. Available online: http://wiki.dpi.inpe.br/doku.php?id=fusaohrccedcbers2b:exemplo (accessed on 13 August 2010).

48. OBT. 2010-Cenarios/Santarem; 2010. Available online: http://www.obt.inpe.br/fototeca/ fototeca.html (accessed on 23 March 2010).

49. IBGE. Agregado de Setores-Pará; 2000. Available online: ftp://geoftp.ibge.gov.br/ (accessed on 23 March 2010).

50. Gavlak, A.A. Aplicação de um método multivariado para geração de superfícies de distribuição populacional. In Proceedings of I Encontro Nacional de Pós-Graduação em Demografia e Áreas Afins, Campinas, Brazil, 22-24 February 2010.

51. Corrêa, R.L. A periodização da rede urbana da Amazônia. Revista Brasileira de Geografia 1987, $39-68$.

52. Oliveira, J.A.A. A cultura na (das) pequenas cidades da Amazônia Brasileira. In Proceedings of IV Congresso Luso-Afro-Brasileiro de Ciências Sociais, Coimbra, Portugal, 16-18 September 2004.

(C) 2012 by the authors; licensee MDPI, Basel, Switzerland. This article is an open access article distributed under the terms and conditions of the Creative Commons Attribution license (http://creativecommons.org/licenses/by/3.0/). 